\title{
PleAse BRING ME THE NEW YORK TIMES ON THE EUROPEAN ROOTS OF RichaRd ABEL MusGraVE
}

\author{
HANS-WERNER SINN
}

\author{
CESIFO WORKING PAPER NO. 2050 \\ CATEGORY 1: PubliC FinANCE \\ JULY 2007
}

\footnotetext{
An electronic version of the paper may be downloaded

- from the SSRN website: Www.SSRN.com

- from the RePEc website: Www.RePEc.org

- from the CESifo website: www.CESifo-group.de
} 


\title{
PleAse BRING ME THE NEW YORK TIMES ON THE EUROPEAN ROOTS OF RICHARD ABEL MusgraVE
}

\begin{abstract}
Richard Musgrave was one of the around 200 academic economists who emigrated from Germany when Fascism came to dominate the country. This memorial lecture traces the German and European roots of Richard Musgrave's oeuvre, trying to shed light on his family background as well as on the political and scientific factors that influenced his education as an economist. Particular emphasis is given to the development of his notion of public goods.
\end{abstract}

JEL Code: H0, B0, B3.

Keywords: Richard Musgrave, Public Finance and Economic Thought.

\author{
Hans-Werner Sinn \\ Ifo Institute for Economic Research \\ at the University of Munich \\ Poschingerstr. 5 \\ 81679 Munich \\ Germany \\ sinn@ifo.de
}

Professor of Economics and Public Finance, Ludwig-Maximilians University, Munich, President of Ifo Institute for Economic Research and President of International Institute of Public Finance. An abridged version of this lecture was given at the Harvard Memorial church on 18 May 2007. The lecture is dedicated to Richard Musgrave's wife, Peggy Musgrave. The author wishes to thank Peggy Musgrave for comments on earlier drafts and Doina Radulescu for research assistance. 
Dear Peggy and dear Friends of Richard Musgrave,

I have come to commemorate Richard Musgrave

- because he was an honorary president of the International Institute of Public Finance,

- because he was one of the godfathers of the Center for Economic Studies and the CESifo Research Network,

- because I learned Public Finance from his writings,

- because he was a personal friend

and, above all,

- because I want to pay tribute to one of the greatest minds of our economics discipline.

Dear Peggy, let me express my deep condolences. That Richard has gone is a loss for us all, but you have lost the man with whom you shared your life, with all its joys and sorrows, successes and failures. We are all grateful to you for giving Richard the strength and intellectual stimulus that kept him active into old age and for taking care of him.

You asked me to speak about Richard's German roots, because others will review his life in America. I am happy to do so as Richard built a bridge between German public finance theory and market theory of the English speaking world over which many important ideas have been transported in both directions.

\section{Exodus}

Richard ranks among the most prominent examples of the intellectual exodus from Germany and Austria after Fascism came to dominate Germany and Hitler's brown-shirt hordes started to trample down the values of humanity. As you know, most of the emigrants were Jews as well as left-wing and liberal intellectuals. The list of famous emigrants is endless. It includes 
people like Albert Einstein, Thomas Mann, Albert Hirschman, Berthold Brecht, Hannah Arendt, Horst Jonas and Samuel (Billy) Wilder. Even the list of economists is long. Among others, it includes Joseph Schumpeter, Gerhard Colm, Gottfried Haberler, Friedrich von Hayek, Walther Lederer, Fritz Machlup, Ludwig von Mises, Karl Roskamp and Wolfgang Stolper. In total, about 200 economists emigrated at the time, 120 of them came to the United States, and one of them was Richard. ${ }^{1}$

Richard Musgrave was a political refugee, and then again he was not. He went to Rochester in the Fall of 1933 with an official stipend of the German student exchange service (Deutscher Akademischer Austauschdienst) which he had been awarded the year before. He did have a return ticket. However, when he realized how things were developing in his home country he wisely decided to stay where he was.

He received his MA in economics at Harvard in 1936 and his $\mathrm{PhD}$ in 1937, ${ }^{2}$ and then had a fabulous world career in economics. ${ }^{3}$ However, before he achieved these degrees, he had already had a thorough education in Germany. As a scholar, he lived two lives, one in the United States, and before that another one in Germany.

\section{Family}

Richard was born in 1910 in Königstein, a small, wealthy town on the hills north of Frankfurt, and he grew up there. I saw pictures of him with a fabulous mansion and an impressive car for a backdrop.

However, the mansion belonged to the sister of his grandmother. Richard Musgrave's father Curt was a writer and cosmopolitan social activist who struggled to make ends meet. He held a doctoral degree in chemistry, but lived primarily on translating books from English into German, among them Rudyard Kipling’s Jungle Book. He also wrote numerous novels

\footnotetext{
${ }^{1}$ See Krohn (1997, p. 46).

${ }^{2}$ See Richard Abel-Musgrave (1937).

${ }^{3}$ For reviews of his achievements see, e.g., Wolfgang Wiegard (1999) or Sijbren Cnossen (2007).
} 
and poems himself, many of which reflected his Search for Democracy, as one of the titles went. ${ }^{4}$ He published 39 books and brochures as well as 13 plays. He wrote about the desperate fate of children in German jails and criticized British juvenile justice. When he documented violent abuse of common soldiers in the German imperial military, he was sentenced to 14 days in military confinement. ${ }^{5}$

In general, Richard’s family had a distinguished intellectual tradition with strong connections to England. His paternal grandfather, Carl Abel, son of a successful banker, Gerson Abel, was a professor of linguistics at the Berlin Humboldt Institute (not the university), a correspondent for the London Times who wrote well-known dispatches from Berlin in the 1870s, taught at Oxford, translated Shakespeare into German and was the author of some 40 books (like his son Curt). He was a member of a liberal intellectual circle at the court around the Kaiser's wife, the daughter of Queen Victoria, and he married into an aristocratic family.

The paternal family originally carried the name Abel, but Richard's father changed the name to Abel-Musgrave, with a hyphen in between, before Richard was born. This happened probably when he registered for what turned out to be only a short stay in the US in 1885 . Richard's father was a friend of, and translator for, Sir Arthur Conan Doyle, the author of the Sherlock Holmes books, and he even lived for some years in Britain. Musgrave, a character in one of these books, seemed to him a useful addition to the name for his frequent contacts with the Anglo-Saxon world. Richard later dropped the hyphen from his father's name when he applied for US citizenship in 1937, becoming then Richard Abel Musgrave. ${ }^{6}$

Richard was of half Jewish ancestry, his paternal grandfather and maternal grandmother both being Jews who had converted to the Christian faith. Richard was brought up as a

\footnotetext{
${ }^{4}$ Curt Abel-Musgrave (1914).

${ }^{5}$ I am grateful to Harry D. Krause, Richard Musgrave’s nephew, the son of his sister Ellen, for providing this information.

${ }^{6}$ His dissertation is listed in Harvard library both under the name Abel-Musgrave and Musgrave.
} 
Lutheran protestant (evangelisch). ${ }^{7}$ However, like his father, he was not really religious, describing himself instead as an agnostic humanitarian. The father had been raised as a protestant but withdrew in the very last moment, on the day before his confirmation, much to his father's annoyance, who had to cancel the festive gathering.

When he was 13, Richard's mother, a mountain climber, died from leukaemia. A year later, Richard Abel-Musgrave was sent to Landschulheim am Solling, a prestigious private boarding school in the town of Holzminden, in northern Germany. There Richard underwent a tough training programme, ranging from poetry to natural sciences, that gave him the intellectual foundation for his later life. In Holzminden he received his Abitur, which at that time was a school-leaving degree obtained by less than five percent of an age group and was comparable to a BA in the Anglo-Saxon world.

\section{Munich}

After the Abitur Richard Musgrave began to study economics at the University of Munich, in 1930. He lived at the Schellingstrasse, where I teach my public finance courses at the University of Munich today. Although he was more interested in skiing than in the subject matter, as he once told me, he did get a good introduction to economics. He attended the lectures of Adolf Weber and Otto von Zwiedineck-Südenhorst.

Adolf Weber taught about macroeconomic problems, public finance and the labour market, but Richard would have preferred to attend the lectures of Max Weber, whose socio-economic view of history he only was able to absorb from his writings. Max had the same family name as Adolf, but was not related to him.

When Richard came to Munich, Max Weber had already passed away and been succeeded by Otto von Zwiedineck-Südenhorst. Zwiedineck taught the marginalist theories of capital and distribution of Eugen von Böhm-Bawerk that John Bates Clark had already brought from

\footnotetext{
${ }^{7}$ Richard Musgrave told me that he once even served as an altar boy in the catholic church, an information that I never understood.
} 
his teacher Karl Knies from Heidelberg University to America. Richard spoke of Zwiedineck with the highest esteem.

I guess Richard's time in Munich is one of the reasons why I was later able to convince him to join the scientific council of the Center for Economic Studies, which was founded in 1991. Richard came nearly every year to our meetings and helped us find the best course, including the transition to the CESifo Research Network in 1999. He also published, in 1991, the very first CES Working Paper, titled "Social Contract, Taxation and the Standing of Deadweight Loss”, which was then published in the Journal of Public Economics. ${ }^{8}$ I am glad to inform you that, to acknowledge his help and commemorate his Munich connections, CESifo has decided to institute an annual Richard Musgrave Visiting Professorship in Munich.

\section{Heidelberg}

Although I come from Munich, I must admit that Richard's studies became more serious after he switched from Munich to Heidelberg in Autumn 1931, after a short intermezzo in Exeter, England. In 1933 he obtained his Diplom-Volkswirt degree there, which is roughly equivalent to an MA in economics. In Heidelberg he was most influenced by Jakob Marschak, Alfred Weber and Otto Pfleiderer.

Jakob Marschak was then a young junior professor who taught the theories of John Maynard Keynes. He had come from the Ukraine in 1919, where he had been involved in the Russian revolution and for a couple of months even held the post of a minister in the Soviet Republic of Terek at the age of 20. When the Nazis came to power he lost his job, emigrated once again, and made his career in the United States as a professor at the University of Chicago and director of the Cowles Commission. Marschak was extremely influential for Richard Musgrave. That Richard included stabilization besides allocation and distribution in

\footnotetext{
${ }^{8}$ Peggy Musgrave and Richard Musgrave (1992).
} 
his list of state functions can be attributed to this early influence as much as to the later contacts with Alvin Hansen in Harvard.

By the way, as Richard said during the celebrations of his ninetieth birthday in Munich, the idea of separating the functions of the government into an allocation, distribution and stabilization branch had come to him after the war, while on an official mission to Germany in the early 1950s where he added a train trip to Kiel to see German economist Erich Schneider. ${ }^{9}$ The article spelling out these functions, which bore the title "A Multiple Theory of Budget Determination,” was published in Finanzarchiv in 1957. Finanzarchiv is the world's oldest public finance journal, founded in 1884 by Georg von Schanz, the inventor of the accrual concept of income taxation. ${ }^{10}$. Finanzarchiv, which switched from German to English in 1999, is now one of the official journals of the International Institute of Public Finance.

Back to Heidelberg! Alfred Weber, the brother of Max Weber, was 64 years old when Richard arrived. In 1909 he had written a ground-breaking book on economic location theory, but he also had written books on the role of culture in economics and on public finance. ${ }^{11}$ Alfred Weber was a liberal who identified himself with the democratic values of the Weimar Republic, which had been created after World War I, and he was opposed to the Nazis. Richard witnessed when Alfred Weber tore down the Swastika flag raised by the SA on his institute and evicted the Nazis from the building. The opposition cost Weber and his assistant Otto Pfleiderer their jobs in 1934, once the dictatorship of Hitler had begun. ${ }^{12}$

Richard often praised the liberal values of the Weimar republic, and throughout his writings he showed the social democratic attitude that had characterized that regime. Alfred Weber had personalized the virtues of that state probably more than anyone else in Richard's life.

\footnotetext{
${ }^{9}$ Musgrave (2001).

${ }^{10}$ See Goode (1976, p.13, and 1977) for a discussion of how this relates to the concepts of Haig and Simons that were developed half a century later.

${ }^{11}$ Alfred Weber (1909, 1912, 1925).

12 See Musgrave (1997), Wiegard (1999), and Nutzinger (1997).
} 
Otto Pfleiderer was Weber’s assistant, a young junior professor like Marschak. Richard said that he had admired him, and he considered Pfleiderer's (1930) book The Public Economy and the Social Product, where Pfleiderer defined the government's contribution to GDP by its input costs, one of highlights of the new wave of public finance writings that had emerged in the second half of the 1920s, resuming, as he said, "the great tradition of the 1860s to '90s when German public finance had been at its height". "Following decades of passivity, the traditional German concern with fiscal theory had again blossomed, public finance was a hot topic, and I was the fortunate beneficiary of that revival," he asserted. ${ }^{13}$

\section{Older Roots}

Among those who had established the older tradition were Adolph Wagner, Albert E.F. Schäffle, Friedrich B.W. von Herrmann and Emil Sax, all of whom had discussed the notion of public goods, which became so important for Richard's writings.

Wagner, a professor of Public Finance in Berlin, came very close to the definition of public goods as it is used today. Wagner was probably the most important among the German Public Finance professors of the time. He was one of the German Socialists of the Chair, or Kathedersozialisten, as they were nicknamed, who had prepared Bismarck’s social reforms. Wagner's $(1880,1883)$ books on Public Finance laid the foundations of public finance of his time and established the field. Wagner thoroughly investigated the reasons for and the kinds of government expenditure. Many of you will have heard of Wagner's Law, which describes the secularly rising trend of government share in GDP. ${ }^{14}$ Particularly important is Wagner's (1892 and 1893) Foundations of Economic Policy because there he defined public goods (Gemeingüter, 1893, pp. 831 -838; cf. also 1883, p. 18) that cannot be provided by the market. The two fundamental criteria, namely

\footnotetext{
${ }^{13}$ Musgrave (1997, pp. 64-65).

${ }^{14}$ See Wagner (1883, § 36, pp.76 n.); cf. also Wagner (1893, pp.892 n., and 1901, p.946). For an extension and discussion of Wagner's law see Timm (1961).
} 
- joint consumption and non-excludability (1893, pp. 866 and 919) and

- non-rivalry (in the sense of being able to service an additional consumer at low or zero marginal costs, 1893, p. 916 and p. 919)

are clearly and prominently presented. ${ }^{15}$

With these definitions Wagner stands in the tradition of Albert E.F. Schäffle and Friedrich B. W. von Hermann. Schäffle (1867, pp. 345, 376, 377) had argued that the state outperforms the competitive exchange economy in the case of goods that serve many people at a time and should be produced only once and for all of them. Von Hermann, the inventor of the upward sloping marginal cost curve, ${ }^{16}$ had already distinguished between exchange goods and free goods, emphasizing the criterion of non-excludability in the sense of the technical impossibility of excluding people from consumption if they do not want to pay the price (von Hermann 1832, pp. 2-5). ${ }^{17}$

Wagner and his predecessors did not attribute the actual or optimal volume of public goods to individual preferences and negotiations but rather held an organic view of the state, i.e. of a state which holds communal preferences that are not just aggregated from individual preferences.

An alternative view was held by Sax (1887), a professor from Prague who had received his Habilitation (post-doctoral degree) in Vienna. He argued in his book on the theory of public finance that the tax bill for satisfying community needs is allocated to individuals such that everyone pays what the public services are worth to him. Despite the joint consumption of public goods, there would be strong analogies to the pricing of individual goods, he argued. This was the first attempt to conceptualize the doctrine of public goods from an individualistic

\footnotetext{
${ }^{15}$ To quote (Wagner 1893, p. 919, my translation): „It comes with the nature of the provision for some kinds of satisfaction of needs that the single individual cannot be excluded from partaking of the respective advantage or utility (consumption), if the provision is made at all. Moreover, the provision often incurs costs that grow little or not at all, at any rate not proportionally, with the enlarged participation in the advantages of the provision."

16 See Erich Streissler (1997).

${ }^{17}$ Von Hermann (1832, p. 331 and p.332) also discussed a criterion of non-consumability, which has certain similarities with the criterion of non-rivalry, but is not identical as he applied it not only to free goods like knowledge, rights and climate, but also to land, for example.
} 
point of view, as we are used to doing today. ${ }^{18}$ But the language Sax used to make his point was rather philosophical, and with today's eyes he is difficult to read.

Richard Musgrave did not endorse Wagner's organic view of the state, which he found too mystical. He leaned more in the direction of Sax. However, he frequently recognized Wagner's contributions in his writings. The way he defined public finance as a discipline for the scholars around the world can be traced back, to a considerable extent, to the comprehensive work of Adolph Wagner, including his distinction between the fiscal and redistributive functions of the state. And even the organic view of the state shines through in Richard's theory of merit goods.

The theory of merit goods was often discarded by contemporary economists whose thinking was based on the principle of methodological individualism. However, it is now finding surprisingly strong support in the new field of behavioural game theory, which demonstrates that people indeed need guidance and that one of the functions of the state might be to provide it. ${ }^{19}$

The criticism was based on the interpretation of merit goods as being an intrinsically paternalistic concept. It is not clear, however, whether this interpretation gives Richard Musgrave full justice. He often expressed this concept as reflecting predominantly social values, very much as a society's rejection of crime as a social value, and, to be fair to his German predecessors, this is probably also the way their organic view of the state should be interpreted.

\section{Swedes}

The breakthrough with the individualistic interpretation of the public goods provision came from Swedish authors Knut Wicksell (1896) and Erik Lindahl (1919), who wrote two major books in German on the issue at the turn of the century. Richard was most impressed by Knut

\footnotetext{
${ }^{18}$ Cf. also Richard Musgrave and Alan Peacock (1964, introduction, p. 14) and Margit Cassel (1925).

${ }^{19}$ See Ted O'Donoghue and Matthew Rabin (2003), Bernheim, Douglas B. and Antonio Rangel (2005).
} 
Wicksell, who developed a view of the state as resulting from a voluntary contract between the individuals and which helped these individuals solve the collective choice problem (Wicksell 1896, esp. pp. 110-138). However, the real progress came from Lindahl (1919, esp. pp. 85-98) who combined the approach with marginal utility theory and tried a formal solution to the implementation problem for public goods, taking up the views of Wicksell and Sax. ${ }^{20}$ His vertical aggregation of individual demand curves for public goods formally came close to the theory Richard presented in his 1939 QJE article The Voluntary Exchange Theory of Public Economy and to what today is called the Samuelson condition for the optimal provision of public goods. ${ }^{21}$ As you know, Richard extended the positive side of the Lindahl solution in his QJE contribution, and Paul Samuelson gave Lindahl's solution a normative interpretation. While the normative interpretation stands firmly on the ground that Paul Samuelson prepared, we know today that Lindahl's solution was not fully incentive compatible, inducing people to misrepresent their true preferences even though some of the problems that Wicksell had seen were overcome. The true incentive-compatible solution of the implementation problem was not found until Edward H. Clarke (1971) and Theodore Groves (1973) published their articles on mechanism design.

To what extent Richard's positive theory will succeed in explaining what is actually happening remains to be seen. As you may know, in 1998 we had a full week of debates on that theme in Munich between Richard Musgrave and Jim Buchanan, between the European social democrat and the dyed-in-the-wool Southerner. ${ }^{22}$ David Warsh (2004), the editor of the Economic Principles weekly, argued in his review article that these "lectures are the most important delivered at the University of Munich since the great Max Weber gave his farewell addresses on politics and science there in $1918,{ }^{23}$ I am not sure whether I fully share this

\footnotetext{
${ }^{20}$ Cf. also the comments of Sax (1924) on Lindahl and Lindahl's (1928) rejoinder.

${ }^{21}$ Musgrave (1939) and Paul Samuelson (1954).

${ }^{22}$ James Buchanan and Richard Musgrave (1999).

${ }^{23}$ A similar opinion was expressed by Sijbren Cnossen (2007). The lecture to which they refer was published as Max Weber (1922).
} 
view, as David Warsh may not have known enough about the numerous Nobel prize winners of the University of Munich's natural science faculties that have lectured there in the meantime. However, I agree that these were indeed outstanding lectures. You can still watch them as high-definition videos on the CESifo website, by the way.

\section{Nobel Prize}

Apart from further developing the theory of public goods, it was Richard Musgrave who set the stage and defined the topics of public finance. He was too modest when he claimed that he just transported prior knowledge over the bridge he had built across the Atlantic. His writings were clearer and at the same time more comprehensive than those of his predecessors. And he added many themes that previously were not considered, including the built-in flexibility of the tax system, taxation and risk taking, the balanced budget multiplier, fiscal federalism, fiscal competition, inter-generation equity, pay-as-you-use, deadweight loss and what have you. Two volumes with collected writings of Richard Musgrave (1986) nicely summarize this work. Musgrave's (1959) Theory of Public Finance was a masterpiece of the human mind that blended the classical themes of German public finance with Anglo-Saxon market theory and Keynesianism, creating an intellectual framework that up to this day serves as a guideline for the public finance economists the world over. ${ }^{24}$ Small wonder that Musgrave’s book, which was soon translated into German, ${ }^{25}$ also became popular in Germany and has dominated the academic curricula ever since its appearance, sweeping away the organic view of the state. Richard Musgrave was able to systemize the topics with his three branches of government activity and helped us understand the diffuse reality of the state in a way that is comparable to how Adam Smith helped us understand the market.

\footnotetext{
${ }^{24}$ The book was later developed into an undergraduate textbook by Peggy Musgrave. See Peggy Musgrave and Richard Musgrave (1973).

${ }^{25}$ See Richard Musgrave (1966). Even Fritz Neumarck (1983), Germany’s last representative of the traditional public finance school, paid tribute to Richard Musgrave's new approach when he gave the laudation for Richard's honorary doctorate degree at the University of Heidelberg.
} 
For this he would have amply deserved the Nobel prize. ${ }^{26}$ I confess that I am one of the disappointed 80 German public finance professors who had proposed Richard Musgrave in vain to the Nobel prize committee some years ago.

While he did not receive the Nobel prize, no less than six universities decided to award him honorary doctorates, among them the universities of Heidelberg (1983) and Munich (2001), the two universities that share the privilege of having been his alma mater.

\section{Personality}

Richard did not know about the endeavours of his admirers, contenting himself with his research and the fact that the economy consisted not only of markets, let alone efficient markets, which would have made public finance superfluous. With his subtle humour he remarked in an interview he gave to Karen Horn (2006) from Frankfurter Allgemeine Zeitung shortly before his passing, "Ich bin den himmlischen Mächten - welche auch immer es sein mögen und wenn es sie überhaupt gibt - dankbar, dass sie den Markt mitsamt dem Markversagen erfunden haben. “ Or, in my translation: "I am thankful to the heavenly powers - whichever they are and if they exist at all - for having created the markets together with the market failures”. This parallels the view he expressed in private conversations when he was in a particularly good mood, that one of the advantages of market failure is that it prompts individuals to work together on a collective solution and to cooperate in correcting the problem.

Richard Musgrave fascinated hundreds of thousands of students throughout the world with his writings about market failure and government functions, and he passed the baton to thousands of them in their research, which he himself had received from his intellectual predecessors in Europe.

Perhaps one of the reasons why his scholars were so fascinated was that Richard admitted

\footnotetext{
${ }^{26}$ Many have argued the same way. See e.g. Wiegard (1999).
} 
frankly that behind his objective reasoning there were strong political convictions. I cite this text from the introduction to his 1959 book The Theory of Public Finance. It is the mission statement which many economists of my generation, including myself, adhered to.

"Unlike some economic purists of today, I admit to more than a scientific motivation; intelligent and civilized conduct of government and the delineation of its responsibilities are at the heart of democracy. Indeed, the conduct of government is the testing ground of social ethics and civilized living. Intelligent conduct of government requires an understanding of the economic relationships involved; and the economists, by aiding this understanding, may hope to contribute to a better society. This is why the field of public finance has seemed of particular interest to me; and this is why my interest in the field has been motivated by a search for the good society, no less than by scientific curiosity.”

And someone who searches for the good society must be a political person who closely follows actual politics rather than the last variations of formal economic theory. The rumour is that John Maynard Keynes’ last words were that his only mistake was not to have drunk enough champagne ${ }^{27}$. Richard Musgrave was not a champagne drinker, and he had stopped reading the Frankfurter Allgemeine Zeitung 73 years ago. ${ }^{28}$ His very last words to his beloved wife Peggy were: "Please bring me the New York Times."

Richard Abel Musgrave died peacefully on 15 January 2007 at the age of 96 . He was buried on Mount Auburn Cemetery in Cambridge next to his father Curt Abel-Musgrave, who had died in 1937.

\footnotetext{
${ }^{27}$ See Kim Phillips-Fein (2002) who cites the sentence "I should have drunk more champagne.”

${ }^{28}$ At that time the newspaper was called Frankfurter Zeitung.
} 
References

Abel-Musgrave, Curt (1914), Auf der Suche nach der Demokratie; Germania, Bamberg.

Abel-Musgrave, Richard (1937), The Theory of Public Finance and the Concept of Burden of Taxation, Dissertation Harvard, mimeo.

Bernheim, Douglas B., and Antonio Rangel (2005), Behavioral Public Economics: Welfare and Policy Analysis with Non-Standard Decision Makers, NBER Working Paper 11518

Buchanan, James M., and Richard A. Musgrave (1999), Public Finance and Public Choice. Two Contrasting Visions of the State, MIT Press, Cambridge, Mass., and London, England.

Cassel, Margit (1925), Die Gemeinwirtschaft. Ihre Stellung und Notwendigkeit in der Tauschwirtschaft, A. Deichertsche Verlagsbuchhandlung, Leipzig and Erlangen.

Clarke, Edward H. (1971), “Multipart Pricing of Public Goods,” Public Choice 11, pp. 17-33

Cnossen, Sijbren (2007), "Richard Musgrave, grondlegger van de moderne publieke economie,” Erflaters, 6 April 2007.

Goode, Richard (1976), The Individual Income Tax, Brookings Institution, Washington, DC.

Goode, Richard (1977), “The Economic Definition of Income,” in: Joseph A. Pechman, ed., Comprehensive Income Taxation, Brookings Institution, Washington DC, pp. 1-36.

Groves, Theodore (1973), “Incentives in Teams,” Econometrica 41, pp. 617-631.

Horn, Karen (2006), “Im Porträt: Richard Musgrave. Der Nestor,“ Frankfurter Allgemeine Zeitung Sonntagszeitung, No. 12, 26 March 2006, p. 48.

Krohn, Klaus-Dieter (1997), “Entlassung und Emigration deutschsprachiger Wirtschaftswissenschaftler nach 1933,“ in: Harald Hagemann, ed., Zur deutschsprachigen wirtschaftswissenschaftlichen Emigration nach 1933, Metropolis-Verlag, Marburg, pp. 3762.

Lindahl, Erik (1919), Die Gerechtigkeit der Besteuerung, Eine Analyse der Steuerprinzipien auf der Grundlage der Grenznutzentheorie, Gleerupska Universitets-Bokhandelen, Lund.

Lindahl, E. (1928), “Einige strittige Fragen der Steuertheorie,“ in: H. Mayer, ed., Die Wirtschaftstheorie der Gegenwart, Ludwig Springer, Vienna, pp. 281-304.

Musgrave, Peggy, and Richard Musgrave (1992), "Social Contract, Taxation and the Standing of Deadweight Loss,” Journal of Public Economics 49, pp. 369-381. (CES Working Paper No. 1, 1991, under Richard Musgrave’s name alone.)

Musgrave, Peggy, and Richard A. Musgrave (1973), Public Finance in Theory and Practice, McGraw Hill, New York.

Musgrave, Richard A. (1939), “The Voluntary Exchange Theory of Public Economy,” Quarterly Journal of Economics 53, pp. 213-237. 
Musgrave, Richard A. (1957), “A Multiple Theory of Budget Determination,” Finanzarchiv N.F. 17, pp. $331-343$.

Musgrave, Richard A. (1959), The Theory of Public Finance. A Study in Public Economy, McGraw-Hill, New-York, Toronto and London.

Musgrave, Richard A., and Alan T. Peacock (1964), eds., Classics in the Theory of Public Finance, MacMillan \& Co., London, and St. Martins Press, New York

Musgrave, Richard A. (1966), Finanztheorie, translation of Musgrave (1959) by Lore Kullmer with collaboration of Hans Fecher, Mohr, Tübingen

Musgrave, Richard A. (1986), Public Finance in a Democratic Society, Volume I,: Social Goods, Taxation and Fiscal Policy, New York University Press, New York.

Musgrave, Richard A. (1986), Public Finance in a Democratic Society, Volume II, Fiscal Doctrine, Growth and Institutions, New York University Press, New York.

Musgrave, Richard A. (1996), "Public Finance and Finanzwissenschaft Compared”, Finanzarchiv N.F. 53, pp. 145-193

Musgrave, Richard A. (1997), "Crossing Traditions,“ in: Harald Hagemann, ed., Zur deutschsprachigen wirtschaftswissenschaftlichen Emigration nach 1933, MetropolisVerlag, Marburg, pp. 63 - 79

Musgrave, Richard A. (2002), Response to Bernd Huber after receiving an honorary doctorate degree from the University of Munich in January 2001, in: Two Anniversaries, Speeches on the Occasion of Richard Musgrave's $90^{\text {th }}$ and CES's $10^{\text {th }}$ Birthdays, CESifo, Munich, mimeo.

Neumarck, Fritz (1983), Laudatio für Richard Musgrave, Heidelberg, 6 May 1983, mimeo.

Nutzinger, Hans G. (1997), “Alfred Weber als Vertreter der inneren Emigration,“ in: Harald Hagemann, ed., Zur deutschsprachigen wirtschaftswissenschaftlichen Emigration nach 1933, Metropolis-Verlag, Marburg, pp. 535 - 548

O'Donoghue, Ted, and Matthew Rabin (2003), “Studying Optimal Paternalism, Illustrated by a Odel of Sin Taxes,” American Economic Review 93, 186-191.

Phillips-Fein, Kim (2002), “The Good Life,” Culture, April 12 $2^{\text {th }}$, http://www. inthesetimes.com/article/1446.

Pfleiderer, Otto (1930), Die Staatswirtschaft und das Sozialprodukt, Gustav Fischer, Jena.

Samuelson, Paul (1954), “The Pure Theory of Public Expenditure,” Review of Economics and Statistics 36, 1954, pp. 387-89

Sax, Emil (1887), Grundlegung der theoretischen Staatswirtschaft, Alfred Hölder, Wien. 
Sax, Emil (1924), “Die Wertungstheorie der Steuer,“ Zeitschrift für Wirtschafts- und Sozialpolitik, N.F. 4, pp. 191-240.

Schäffle, Albert E. F. (1867), Das gesellschaftliche System der menschlichen Wirtschaft - ein Lehr- und Handbuch der Nationalökonomie, 2nd edition, Laupp \& Siebeck, Tübingen.

Streissler, Erich W. (1997), Friedrich Benedikt Wilhelm von Hermann: Anatomie einer wissenschaftlichen Verwandlung, Abhandlungen der Bayerischen Akademie der Wissenschaften, Vol. 9, C. H. Beck, München.

Timm, Herbert (1961), “Das Gesetz der wachsenden Staatsausgaben,“ Finanzarchiv N.F.21, pp. 201-247.

von Hermann, Friedrich B. W. (1832), Staatswirthschaftliche Untersuchungen über Vermögen, Wirthschaft, Productivität der Arbeiten, Kapital, Preis, Gewinn, Einkommen und Verbrauch, Anton Weber'sche Buchhandlung, München.

Wagner, Adolph (1880), Finanzwissenschaft, Zweiter Theil, Gebühren und allgemeine Steuerlehre, C. F. Winthersche Verlagsbuchhandlung, Leipzig and Heidelberg.

Wagner, Adolph (1883), Finanzwissenschaft, Erster Theil, Einleitung, Ordnung der Finanzwirthschaft, Finanzbedarf, Privaterwerb, 3rd edition, C. F. Winthersche Verlagsbuchhandlung, Leipzig.

Wagner, Adolph (1892 and 1893), Grundlegung der politischen Ökonomie, Erster Theil, Grundlagen der Volkswirtschaft, two parts, C. F. Winthersche Verlagsbuchhandlung, Leipzig.

Wagner, Adolph (1901), “Staat in nationalökonomischer Hinsicht,“ in: Johannes Conrad, ed., Handwörterbuch der Staatswissenschaften, Vol. VII, second edition, pp. 940-951, Gustav Fischer, Jena

Warsh, David (2004), “Architect of the Public Household,” Economic Principles.com, 15 February, 2004

Weber, Alfred (1909), Über den Standort der Industrie: Reine Theorie des Standorts, Mohr, Tübingen.

Weber, Alfred (1912), Religion und Kultur, Diederichs, Jena.

Weber, Alfred (1925), Die Krise des modernen Staatsgedankens in Europa, Deutsche Verlagsanstalt, Stuttgart.

Weber, Max (1922), “Politik als Beruf,” Gesammelte Aufsätze zur Wirtschaftslehre, pp 395450. Mohr, Tübingen.

Wicksell, Knut (1896), Finanztheoretische Untersuchungen nebst Darstellung und Kritik des Finanz- und Steuerwesens Schwedens, Gustav Fischer, Jena. 
Wiegard, Wolfgang (1999) "Richard Abel Musgrave, ” in: Harald Hagemann and ClausDieter Krohn, eds., Biographisches Handbuch der deutschsprachigen wirtschaftswissenschaftlichen Emigration nach 1933, Vol II, K. G. Saur, München, pp. 479-483. 


\title{
CESifo Working Paper Series
}

\author{
(for full list see www.cesifo-group.de)
}

1988 Erkki Koskela and Rune Stenbacka, Equilibrium Unemployment with Outsourcing and Wage Solidarity under Labour Market Imperfections, May 2007

1989 Guglielmo Maria Caporale, Juncal Cunado and Luis A. Gil-Alana, Deterministic versus Stochastic Seasonal Fractional Integration and Structural Breaks, May 2007

1990 Cláudia Costa Storti and Paul De Grauwe, Globalization and the Price Decline of Illicit Drugs, May 2007

1991 Thomas Eichner and Ruediger Pethig, Pricing the Ecosystem and Taxing Ecosystem Services: A General Equilibrium Approach, May 2007

1992 Wladimir Raymond, Pierre Mohnen, Franz Palm and Sybrand Schim van der Loeff, The Behavior of the Maximum Likelihood Estimator of Dynamic Panel Data Sample Selection Models, May 2007

1993 Fahad Khalil, Jacques Lawarrée and Sungho Yun, Bribery vs. Extortion: Allowing the Lesser of two Evils, May 2007

1994 Thorvaldur Gylfason, The International Economics of Natural Resources and Growth, May 2007

1995 Catherine Roux and Thomas von Ungern-Sternberg, Leniency Programs in a Multimarket Setting: Amnesty Plus and Penalty Plus, May 2007

1996 J. Atsu Amegashie, Bazoumana Ouattara and Eric Strobl, Moral Hazard and the Composition of Transfers: Theory with an Application to Foreign Aid, May 2007

1997 Wolfgang Buchholz and Wolfgang Peters, Equal Sacrifice and Fair Burden Sharing in a Public Goods Economy, May 2007

1998 Robert S. Chirinko and Debdulal Mallick, The Fisher/Cobb-Douglas Paradox, Factor Shares, and Cointegration, May 2007

1999 Petra M. Geraats, Political Pressures and Monetary Mystique, May 2007

2000 Hartmut Egger and Udo Kreickemeier, Firm Heterogeneity and the Labour Market Effects of Trade Liberalisation, May 2007

2001 Andreas Freytag and Friedrich Schneider, Monetary Commitment, Institutional Constraints and Inflation: Empirical Evidence for OECD Countries since the 1970s, May 2007

2002 Niclas Berggren, Henrik Jordahl and Panu Poutvaara, The Looks of a Winner: Beauty, Gender, and Electoral Success, May 2007 
2003 Tomer Blumkin, Yoram Margalioth and Efraim Sadka, Incorporating Affirmative Action into the Welfare State, May 2007

2004 Harrie A. A. Verbon, Migrating Football Players, Transfer Fees and Migration Controls, May 2007

2005 Helmuth Cremer, Jean-Marie Lozachmeur and Pierre Pestieau, Income Taxation of Couples and the Tax Unit Choice, May 2007

2006 Michele Moretto and Paolo M. Panteghini, Preemption, Start-Up Decisions and the Firms’ Capital Structure, May 2007

2007 Andreas Schäfer and Thomas M. Steger, Macroeconomic Consequences of Distributional Conflicts, May 2007

2008 Mikael Priks, Judiciaries in Corrupt Societies, June 2007

2009 Steinar Holden and Fredrik Wulfsberg, Downward Nominal Wage Rigidity in the OECD, June 2007

2010 Emmanuel Dhyne, Catherine Fuss, Hashem Pesaran and Patrick Sevestre, Lumpy Price Adjustments: A Microeconometric Analysis, June 2007

2011 Paul Belleflamme and Eric Toulemonde, Negative Intra-Group Externalities in TwoSided Markets, June 2007

2012 Carlos Alós-Ferrer, Georg Kirchsteiger and Markus Walzl, On the Evolution of Market Institutions: The Platform Design Paradox, June 2007

2013 Axel Dreher and Martin Gassebner, Greasing the Wheels of Entrepreneurship? The Impact of Regulations and Corruption on Firm Entry, June 2007

2014 Dominique Demougin and Claude Fluet, Rules of Proof, Courts, and Incentives, June 2007

2015 Stefan Lachenmaier and Horst Rottmann, Effects of Innovation on Employment: A Dynamic Panel Analysis, June 2007

2016 Torsten Persson and Guido Tabellini, The Growth Effect of Democracy: Is it Heterogenous and how can it be Estimated?, June 2007

2017 Lorenz Blume, Jens Müller, Stefan Voigt and Carsten Wolf, The Economic Effects of Constitutions: Replicating - and Extending - Persson and Tabellini, June 2007

2018 Hartmut Egger and Gabriel Felbermayr, Endogenous Skill Formation and the Source Country Effects of International Labor Market Integration, June 2007

2019 Bruno Frey, Overprotected Politicians, June 2007 
2020 Jan Thomas Martini, Rainer Niemann and Dirk Simons, Transfer Pricing or Formula Apportionment? Tax-Induced Distortions of Multinationals' Investment and Production Decisions, June 2007

2021 Andreas Bühn, Alexander Karmann and Friedrich Schneider, Size and Development of the Shadow Economy and of Do-it-yourself Activities in Germany, June 2007

2022 Michael Rauscher and Edward B. Barbier, Biodiversity and Geography, June 2007

2023 Gunther Schnabl, Exchange Rate Volatility and Growth in Emerging Europe and East Asia, June 2007

2024 Erkki Koskela and Ronnie Schöb, Tax Progression under Collective Wage Bargaining and Individual Effort Determination, June 2007

2025 Jay Pil Choi and Marcel Thum, The Economics of Politically Connected Firms, June 2007

2026 Jukka Pirttilä and Roope Uusitalo, Leaky Bucket in the Real World: Estimating Inequality Aversion Using Survey Data, June 2007

2027 Ruslan Lukach, Peter M. Kort and Joseph Plasmans, Strategic R\&D with Knowledge Spillovers and Endogenous Time to Complete, June 2007

2028 Jarko Fidrmuc, Neil Foster and Johann Scharler, Labour Market Rigidities, Financial Integration and International Risk Sharing in the OECD, June 2007

2029 Bernardina Algieri and Thierry Bracke, Patterns of Current Account Adjustment Insights from Past Experience, June 2007

2030 Robert Dur and Hein Roelfsema, Social Exchange and Common Agency in Organizations, June 2007

2031 Alexander Libman and Lars P. Feld, Strategic Tax Collection and Fiscal Decentralisation: The Case of Russia, June 2007

2032 Øystein Foros, Hans Jarle Kind and Greg Shaffer, Resale Price Maintenance and Restrictions on Dominant Firm and Industry-Wide Adoption, June 2007

2033 Jan K. Brueckner and Kurt Van Dender, Atomistic Congestion Tolls at Concentrated Airports? Seeking a Unified View in the Internalization Debate, June 2007

2034 Viet Do and Ngo Van Long, International Outsourcing under Monopolistic Competition: Winners and Losers, June 2007

2035 Nadia Fiorino and Roberto Ricciuti, Determinants of Direct Democracy, June 2007

2036 Burkhard Heer and Alfred Maussner, Inflation and Output Dynamics in a Model with Labor Market Search and Capital Accumulation, June 2007 
2037 Konstantinos Angelopoulos, Jim Malley and Apostolis Philippopoulos, Public Education Expenditure, Growth and Welfare, June 2007

2038 Maarten Bosker, Steven Brakman, Harry Garretsen and Marc Schramm, Adding Geography to the New Economic Geography, June 2007

2039 Steffen Henzel, Oliver Hülsewig, Eric Mayer and Timo Wollmershäuser, The Price Puzzle Revisited: Can the Cost Channel Explain a Rise in Inflation after a Monetary Policy Shock?, July 2007

2040 Rosario Crinò, Service Offshoring and White-Collar Employment, July 2007

2041 Carsten Hefeker and Michael Neugart, Labor Market Regulation and the Legal System, July 2007

2042 Bart Cockx and Muriel Dejemeppe, Is the Notification of Monitoring a Threat to the Unemployed? A Regression Discontinuity Approach, July 2007

2043 Alfons J. Weichenrieder, Profit Shifting in the EU: Evidence from Germany, July 2007

2044 Annika Alexius and Bertil Holmlund, Monetary Policy and Swedish Unemployment Fluctuations, July 2007

2045 Axel Dreher, Jan-Egbert Sturm and Jakob de Haan, Does High Inflation Cause Central Bankers to Lose their Job? Evidence Based on a New Data Set, July 2007

2046 Guglielmo Maria Caporale and Luis A. Gil-Alana, Long Run and Cyclical Dynamics in the US Stock Market, July 2007

2047 Alessandro Balestrino, It is a Theft but not a Crime, July 2007

2048 Daniel Becker and Michael Rauscher, Fiscal Competition in Space and Time: An Endogenous-Growth Approach, July 2007

2049 Yannis M. Ioannides, Henry G. Overman, Esteban Rossi-Hansberg and Kurt Schmidheiny, The Effect of Information and Communication Technologies on Urban Structure, July 2007

2050 Hans-Werner Sinn, Please Bring me the New York Times - On the European Roots of Richard Abel Musgrave, July 2007 